\section{THE CURRICULAR ROLE OF RUSSELL'S SCEPTICISM}

Michael J. Rockler

Interdisciplinary Studies in Education / National-Louis University

Evanston, IL 6020I, U SA

$\mathrm{I}$

The Prospects of Industrial Civilization, written in collaboration with his wife Dora, Bertrand Russell wrote:

The governors of the world believe, and have always believed, that virtue can only be taught by teaching falsehood, and that any man who knew the truth would be wicked. I disbelieve this, absolutely and entirely. I believe that love of truth is the basis of all real virtue, and that virtues based upon lies can only do harm.

This passage reflects Russell's views on scepticism and education; he sought an educational system that would avoid indoctrination and would produce sceptical students. Scepticism, a central aspect of much of Russell's philosophic work, was a primary organizing principle of his writings on education.

Russell, a major contributor to educational theory, produced two volumes on education that continue to have considerable relevance for teaching and learning in contemporary society. The first, Education and the Good Life (1926), ${ }^{2}$ inspired by the births of John and Katharine, focused on the education of young children. In Education and the Good Life, Russell identified the aims of education. These included the development of vitality, the promotion of courage (which entails the absence of fear), sensitiveness and intelligence. When schools accomplish these ends, they produce young men and women of character who are able to contribute to the well-being of society.

I (London: Allen \& Unwin, 1923), p. 252.

2 Published in Britain as On Education: Especially in Early Childhood.
Russell, who once stood for Parliament as suffragist candidate, believed in equality of education for both men and women. This position was well advanced for its time; it still encounters resistance today.

As the Russells' children approached school age, he and Dora confronted the problem of their education. Russell did not want John and Katharine to experience the loneliness of education by tutors that he had faced as a child. He and Dora also wished to avoid conventional public schools because they wanted their children to be educated in a manner consistent with their sense of scepticism about society and about religion. Russell felt that exposure to any kind of traditional learning would cause his children to be indoctrinated with patriotic and religious points of view. On the other hand, he felt that the progressive schools that were available-including A.S. Neill's Summerhill-lacked intellectual rigour. As a result of these feelings and because of Dora Russell's interest in education, the Russells leased the estate of Bertrand's brother at Telegraph House in Sussex and founded what came to be known as Beacon Hill School in September 1927.

With his experience at Beacon Hill in mind, Russell published a second book on education in 1932-Education and the Modern World. ${ }^{3}$ It argued against the notion of progressive educators that schooling should simply allow for natural growth. Russell rejected Rousseau's approach to teaching and learning, and he distanced himself from some of Dewey's early work as well.

In Education and the Good Life, and in other early essays on learning theory, Russell had seemed impressed by the growing role of behaviourism in education. However, his experience at Beacon Hill and his reading of psychoanalytic literature weakened his acceptance of behaviourism. In Education and the Modern World Russell called for more awareness of the role of emotion in learning as well as an examination of the way in which repressed feelings affect action. Russell argued that conditioning cannot effectively develop character.

Education and the Modern World ends on a discouraging note. Russell concludes that schools can only provide for full individual development if the state identifies its own interest with that of the

${ }^{3}$ Published in Britain as Education and the Social Order. 
child. Russell was pessimistic about this possibility. For this to take place, a number of things had to occur. First, large scale wars had to be eliminated. Second, superstition had to vanish. Third, the love of uniformity had to be extinguished. Finally, schools had to be administered by scholars rather than by bureaucrats. Russell concluded that that could not happen in society as it was constituted in 1932. A new social order was necessary; education could bring this about, but not until a change in perspective occurred.

Russell never wrote a third book on education. His separation and divorce from Dora led to his separation from Beacon Hill School. However, he continued to be interested in education throughout his life and returned to issues of teaching and learning in many of his other writings. Russell believed that schooling could ultimately restore society if it produced scepticism and ended indoctrination in patriotism and religion.

\section{RUSSELL AND SCEPTICISM}

A context for Russell's scepticism can be obtained from the work of Paul Kuntz. His volume on Russell, published in $1986,{ }^{4}$ argues that Russell participated in five great rebellions; these influenced his views on education and supported his scepticism.

The first of these great rebellions was against parental authority. Russell, according to Kuntz, reacted against his grandmother's puritanism. This led to his belief that education should maximize independence and freedom for individuals. Beacon Hill School was a product of this rebellion. Russell also revolted against the notion that pleasure in general, and sexual pleasure in particular, was evil. This resulted in his views on sexual freedom and his opposition to the concept of monogamy. It also led to his rejection of shame about nudity. A third rebellion involved the rejection of patriotic loyalty to the nation-state and resulted in Russell's unwillingness to support all wars. This caused him considerable difficulty at the time of the First World War. It also led to his opposition to the Vietnam War-the last great battle of his life. Russell also rebelled against inequality based on either birth or

4 Bertrand Russell (Boston: Twayne, 1986). wealth. This led to his advocacy of socialism, a position which he modified as he grew older but never abandoned. While rejecting the Soviet application of Marxism, Russell remained convinced that some form of communal life was a more equitable way to organize society.

Kuntz argues that all four of these rebellions led to the fifth. He writes:

These are four radical revisions of the institutions of child rearing and education, marriage, citizenship, and economic order. These four are united in fifth, the rebellion against the tradition of basing child rearing and education in reverence for divinely appointed parents, marriage formulated in holy matrimony, loyalty to king and country as forms of loyalty to God, and property as the sacred trust binding the generations.

The modern rebellion is a rebellion against religious tradition, particularly against basing the ultimate justification on the command of God. If religious sentiment reinforces all the structures of life against which the modernist Russell is rebelling, and the religious institution of the church stands in the way, then religion becomes the greatest block to progress, the last of the great evils to be destroyed. (P. 5)

These five rebellions, taken together, removed Bertrand Russell from the traditional moorings that link most people to society. Each of these rebellions came from a deep scepticism of the status quo; each reinforced further doubt. Once Russell broke from parental authority, it freed him to turn his inquiring and brilliant mind to the critique of other traditions. Russell's scepticism opened new vistas for him and for large numbers of people who directly or indirectly accepted some or all of his views. Because of this, Russell's scepticism may be his greatest contribution to modern thought in general and educational thought in particular.

Alan Ryan, in his biography of Russell, suggests that Russell's moral philosophy can be called consequentialism. ${ }^{5}$ By this he means that Russell reached conclusions about events and actions based on what he believed the results of these actions might be. Consequentialism also reinforces scepticism because it forces one to look at the possible outcomes of behaviour and to examine alternative courses of action. Once a person becomes accustomed to looking for other ways of acting, the

\footnotetext{
s Bertrand Russell: a Political Life (New York: Hill and Wang, 1988), p. 34
} 
range of possibilities governing any action is expanded. This then tends to make a person more uncertain and therefore more sceptical about the correctness of any given course of action, procedure or thought.

Russell labelled his own philosophy "logical atomism". He argued that ideas should be analyzed until they could not be dissected any further. At this point the logical atom of analysis will have been reached. Logical atomism also reinforces scepticism because it requires the constant analysis of problems into smaller and smaller units, resulting in a process of continual questioning. Russell, in many writings, indicates his agreement with fallibilism-the need to continually question the validity of any stated proposition. Fallibilism, like scepticism, is one of the practical consequences of logical atomism.

Given the preceding context, it is possible to analyze and define Russell's views on scepticism. His volume, Sceptical Essays, is a major source of this perspective. In the Introduction, Russell writes:

I wish to propose for the reader's favourable consideration a doctrine which may, I fear, appear wildly paradoxical and subversive. The doctrine in question is this: that it is undesirable to believe a proposition when there is no ground whatever for supposing it true. ${ }^{6}$

If this were accepted, Russell argues, both social life and political system would be transformed. This statement sets the stage for Russell's case for scepticism.

Russell takes the position that when experts are agreed, it is unwise to hold that an opposite opinion is certain; and that when experts disagree, no opinion can be held with certainty by a non-expert. He says that when all experts take the stand that no sufficient grounds exist for a positive opinion, the ordinary man ought to withhold judgment. Russell says, "These propositions may seem mild, yet, if accepted, they would absolutely revolutionize human life" (p. I3). He continues his argument by saying that when good grounds for holding an opinion are lacking, the opinion is often held with even greater passion. Furthermore, sceptics are hated while passionate holders of erroneous points of view are tolerated.

${ }^{6}$ (London: Allen \& Unwin, I928), p. II.
In a later chapter in Sceptical Essays, Russell turns to an examination of the process of free thought. It exists when open competition among beliefs exists. Russell felt that legal and financial restraints affect the competitive nature of beliefs and therefore this "is an ideal which, for various reasons, can never be fully attained. But it is possible to approach very much nearer to it than we can do at present." 7 In place of free thought the state indoctrinates children in order to make them believe "absurd propositions, the effect of which is to make them willing to die in defence of sinister interests under the impression that they are fighting for truth and right" (p. I55). This is done to a greater or lesser extent by all states.

Russell argued that scepticism could revolutionize social life. He also felt that improved education could lead to a freer, more rational and ultimately more satisfying society. In fact, the application of Russell's scepticism to education can improve the nature of teaching and learning in contemporary society and move human social life toward the ideals that Russell envisioned.

\section{CURRICULAR IMPLICATIONS OF RUSSELL'S SCEPTICISM}

Russell often addressed curricular issues in his writings; several implications for curriculum follow from Russell's views on scepticism.

I. Scepticism requires that rationalism be a primary focus of the curriculum.

Sceptical Essays addresses the importance of reason. In a chapter called "Can Men be Rational?" Russell proposes:

To begin with rationality in opinion: I should define it merely as the habit of taking account of all relevant evidence in arriving at a belief. Where certainty is attainable, a rational man will give most weight to the most probable opinion, while retaining others, which have an appreciable probability, in his mind as hypotheses which subsequent evidence may show to be preferable. (Pp. 45-6)

Without thinking about it, many persons might conclude that

7 In "Free Thought and Official Propaganda", Sceptical Essays, p. I49. 
rationalism is a given in educating children, but this is not the case. In fact, schools have objectives which interfere with facilitating the use of reason. This was true in Russell's time and it continues to be true today. Schools subvert rational thinking in at least two curricular areas: patriotism and religion.

Russell opposed the use of schools to indoctrinate students with nationalistic feelings. He felt that this kind of teaching legitimized support for war. He and Dora founded Beacon Hill School, in part, to prevent their children from being exposed to patriotic indoctrination. Unfortunately, emphasis on national pride remains a problem in contemporary education. Students are still taught patriotic history; critical analysis of political events and leaders is discouraged. Many educators continue to argue that schools should provide civic education. Russell believed that the teaching of patriotism could only foster irrational perspectives and support the tendency to believe ideas for which no evidence exists.

Religion also continues to be part of education in many countries, including the United States. Christian holidays, most notably Christmas, have become part of the culture. While the Supreme Court so far continues to prohibit prayer in the schools, religious pageants during the Christmas and Easter seasons involve students in what is clearly religious activity. The Reagan and Bush years have exacerbated this problem. Irrationalism also exists in demands that creationism be afforded equal status with the teaching of evolution.

A rational curriculum founded on scepticism remains a primary need of education. Russell's arguments for the efficacy of truth continue to be valid. Contemporary sceptics must seek to prevent irrational beliefs from being part of the curriculum. Schools would be more effective institutions if they accepted Russell's contention that education be primarily a secular enterprise, free of any religious content.

2. Scepticism requires that schools at all levels be institutions of free inquiry.

The scientific method remains the most productive way to obtain information about the universe. There are legitimate alternative ways of knowing (through aesthetic means, for example), but scientific problem-solving is the primary method of serious scholarship. This means that the use of inquiry must be a major strategy in teaching and learning from kindergarten through graduate school.

In Chapter I2 of Sceptical Essays, Russell provides an example of how the method of free inquiry can be applied to teaching practice:

If there is to be toleration in the world, one of the things taught in schools must be the habit of weighing evidence, and the practice of not giving full assent to propositions which there is no reason to believe true. For example, the art of reading newspapers should be taught. The schoolmaster should select some incident which happened a good many years ago, and roused political passions in its day. He should then read to the school-children what was said by the newspapers on one side, what was said by those on the other, and some impartial account of what really happened. He should show how, from the biased account of either side, a practised reader could infer what really happened, and he should make them understand that everything in newspapers is more or less untrue. The cynical scepticism which would result from this teaching would make the children in later life immune from those appeals to idealism by which decent people are induced to further the schemes of scoundrels. (Pp. 165-6)

Russell argues for instruction in the scientific temper, which he distinguishes from the teaching of scientific products. The former leads to the development of free thought, while undue study of the latter can lead to a mechanistic view of the world in which learning about results becomes more important than learning the process of inquiry. Inquiry has established a foothold in curriculum as a result of the prestige of science and because of the curriculum revolution that occurred in the United States in the 1960s. However, the existence of free inquiry is always in jeopardy; its survival must be a goal of those followers of Russell who believe in the value of scepticism.

3. Fallibilism is an important educational perspective.

Fallibilism, a perspective that follows from scepticism, is a point of view that ought to be part of the curriculum. Fallibilism denies authority as a source of truth. It teaches students to find answers by using the scientific method; it dilutes the importance of educational experts who define curricular topics and procedures on the basis of authority.

Philosophic fallibilism takes the position that science advances by demonstrating that existing scientific hypotheses are false. This makes it a significant application of scepticism. It is a position that recognizes 
the fallibility of all human beings. Students learning this perspective become suspicious of all claims of infallibility. They recognize that the goal of education is not certainty but improvement.

A school founded on fallibilism would encourage students to continually examine beliefs-their own and those of the people around them-in order to eliminate falsehood and to create more accurate formulations of reality. Fallibilism is very threatening to school administrators because once the use of authority is denied with regard to ideas, the authority of the institution itself can be questioned. Nonetheless, the fallibilistic perspective can result in more effective schooling because it relies on the search for truth and the denial of false propositions.

If schools applied Russell's scepticism to the curriculum and adopted a fallibilistic perspective, many who instruct by relying on authority would leave teaching. This in and of itself could lead to major improvements in schooling.

4. Scepticism requires a global rather than a national perspective in the classroom.

As indicated above, Russell was an opponent of the teaching of patriotism in the schools. He was an internationalist who believed in world government. Scepticism led him to conclude that individual nation-states would proceed from narrow perceptions of self-interest. The frequent result of this was violent conflict. During all of Russell's life, major wars were in progress or nations were preparing for them. War occurs when a nation becomes certain that its self-interest will best be served by armed conflict. A sceptical, fallibilistic perspective mitigates against certainty and weakens the tendency to employ violent solutions to problems.

A curriculum based on scepticism emphasizes international studies. Once schools are freed from the need to teach the superiority of a single nation, more time can be devoted to the study of other countries. This will produce a less provincial education, one in which pupils understand the nature and variety of the human family. Ultimately, this could help bring about world government.
5. A curriculum based on the sceptical perspective requires the study of values and value clarification.

A curriculum based on certainty seeks to indoctrinate students with the dominant values of the state. One based on scepticism requires a process in which pupils learn to analyze the genesis of their own values and to clarify their value positions. Educational setrings which are value-free do not exist. Scepticism is itself a value position; so is what Russell labels as the scientific temper. The sceptical curriculum perspective is one in which students understand the nature of values, comprehend the existence of value conflict, clarify their own value positions and learn to be consequentialists by studying the implications of their positions.

Education must foster the development of freedom of action and thought. This is the ultimate purpose of teaching and learning. This emerges directly from Russell's scepticism. Only a free human being can be a sceptical one; conversely, only a sceptical person can ultimately achieve genuine freedom.

\section{ROLE OF THE TEACHER IN THE SCEPTICAL SCHOOL}

Russell applied his sceptical perspective to curricular questions and was also interested in the nature of teaching. He returned to teacher education in many of his writings.

In The Prospects of Industrial Civilization, he notes the importance of instruction:

The best hope is with the teachers. What the teachers could insist upon is complete freedom so long as the actual instruction is satisfactory. That is to say, they could demand, and secure, that a teacher in a State school should not suffer by reason of his opinions, or the opinions which he expresses in teaching, or his activities outside school hours, so long as there is no fault to be found with the actual knowledge of his pupils. (P. 246)

Russell argues in the same volume that teachers cannot be impartial because this usually means that the teacher will take the position supported by the educational authorities. But, the best teachers "are not impartial; they are men of strong enthusiasms, to which they wish to give expression in their teaching" (p. 248).

Students can best obtain impartial education, Russell argues, when 
they are exposed to a variety of opinionated persons. Truth will emerge when a pupil examines the contradictions he or she obtains from listening to persons with different opinions on the same subject. Russell concludes this section by writing: "If the result is scepticism as to all violent opinions, so much the better; that is the very attitude of mind that the modern world most needs in the mass of mankind" ( $p$. 248)

In Unpopular Essays, published in I950, Russell includes a chapter entitled "The Functions of a Teacher". ${ }^{8}$ In it he analyzes some of the problems facing teachers. He argues that instructors are overworked. Teaching cannot be effective when it must be done for several hours a day. The work is too demanding, and it does not leave sufficient time or energy for further study. Furthermore, teachers are not allowed to have opinions; they must instead become propagandists for the state. Russell refers to courses taught in the United States which are called "Civics" and argues that in these classes the teaching is expected to be misleading. He says: "The young are taught a sort of copybook account of how public affairs are supposed to be conducted, and are carefully shielded from all knowledge as to how in fact they are conducted" (p. I20). Students taught this way grow up and discover the truth; this often makes them cynical and can lead them to accept evil. Russell cannot accept the notion that falsehood is edifying; he call it "one of the besetting sins of those who draw up educational schemes" (ibid.).

The teacher of a curriculum based on scepticism must be free and able to express his or her opinions honestly. She must have time to reflect and to learn. Ultimately she must be a sceptic

In conclusion, Russell produced considerable writing about education. Much of his work remains valid for education in the twenty-first century. Schooling would be improved if it adopted the ideas of this remarkable educational thinker born in the nineteenth century.

${ }^{8}$ (New York: Simon and Schuster, 1950). 